\title{
POSTRZEGANIE I KATEGORYZACJA BARW (ŚWIAT LUDZI I ZWIERZĄT)
}

\author{
ANDRZEJ NARLOCH
}

Tylko ja mogę rozprawiać o kolorach, powiedzial daltonista, bo ja jestem bezstronny.

Wiesław Brudziński

\section{Wstęp}

Świat postrzegamy za pomocą pięciu organów zmysłów. Każdy z nich jest odpowiedzialny za odbiór ściśle określonego rodzaju informacji docierającego ze świata zewnętrznego. Informacje te umysł ludzki odbiera jako dotyk, dźwięk, smak, węch, wrażenie wizualne. Każdy zmysł ze względu na uwarunkowania biologiczne i neurofizjologiczne ma różny udział w dostarczaniu danych do mózgu człowieka. Badania dowodzą, że słuch dostarcza $5 \%$ danych, dotyk $-2 \%$, smak $-2 \%$, węch $-1 \%$. Najwięcej informacji dociera jednak do mózgu poprzez wzrok, bo aż $90 \%$.

Jak pisze Anna Wierzbicka, „To, co się pojawia w siatkówce i w mózgu, nie odbija się bezpośrednio w języku. Język odbija to, co dzieje się w umyśle, a nie to, co dzieje się w mózgu; nasz umysł zaś jest po części kształtowany przez konkretną kulturę" . Narządy zmysłów przekazują informacje do mózgu, w którym są one przetwarzane, odbijając się w umyśle w postaci różnorakich wrażeń, na które reagujemy, wchodząc w interakcje z otaczającym środowiskiem.

Wszystko, co nas otacza, posiada swoją barwę, dlatego jest ona jednym z najistotniejszych atrybutów opisu rzeczywistości. Poeci i pisarze, malując świat swoich

\footnotetext{
${ }^{1}$ A. Wierzbicka, Semantyka. Jednostki elementarne i uniwersalne, Lublin 2006, s. 329.
} 
bohaterów, przedmiotów, przyrody, krajobrazu, niejednokrotnie wykorzystują kolor jako element charakterystyki, kreujący świadomy i zamierzony nastrój wkomponowany w ideę artystyczną. Kolor jest jedną z fizycznych właściwości przedmiotu w opinii językoznawców jest cechą inherentną, niezbywalną, definicyjną ${ }^{2}$. W kulturze i społeczeństwie kolorowi wyznacza się określone zadania i cele. Pełni on wiele funkcji w procesach tworzenia znaków semiotycznych. W zależności od kontekstu, w którym funkcjonuje, staje się nośnikiem różnorakich znaczeń - informacyjnych, komunikacyjnych, estetycznych, symbolicznych, perswazyjnych, integrujących $^{3}$.

\section{Postrzeganie barwy - świat ludzi i zwierząt}

Ludzie i zwierzęta postrzegają barwy w taki sposób, w jaki wyposażyła ich natura. Dlatego budowa biologiczna narządów wzroku determinuje percepcję otaczającej rzeczywistości. Świat widziany dzięki receptorom wzroku jest światem tych bodźców, do odbierania których zostały przeznaczone poszczególne receptory. Oko człowieka i małp naczelnych ma 3 receptory (czopki) kolorów: czerwony, zielony i niebieski, oraz tzw. pręciki, które odpowiadają za widzenie czarno-białe, tj. rozróżnianie kształtów oraz stopień jasności obiektów. Korzystając ze swojego aparatu widzenia, człowiek postrzega spektrum barwne, określane jako zakres barw od czerwonego, poprzez pomarańczowy, żółty, zielony, niebieski, indygo, aż do fioletowego. Jest to tzw. siedem kolorów tęczy, które opisał już w XVII wieku na podstawie rozszczepienia światła w pryzmacie angielski fizyk Izaak Newton.

Z powyższych rozważań wynika, że czynniki neurofizjologiczne determinują zakres odbieranych fal elektromagnetycznych. Dla człowieka zakres ten rozciąga się w przedziale $380-780 \mathrm{~nm}$. I przez pryzmat tych fal elektromagnetycznych odbieramy otaczający świat. Z całego dostępnego wachlarza fal występujących w przyrodzie te widziane przez człowieka stanowią jednak jego niewielką część. Wierzbicka pisze, powołując się na S. Witkowskiego i C. Browna, że „cztery klasy kolorów, czerwony, żółty, zielony i niebieski, [...] są neurofizjologicznie 'zaprogramowane' w istotach ludzkich" ". Jednakże ów zakres nie jest jedynym, obiektywnym narzędziem, który może być przyłożony do interpretacji materialnego świata. Nasze receptory wzroku nie są uniwersalnym narzędziem uzyskiwania informacji o świecie, dlatego nie można uznać je za jedyne i uniwersalne.

${ }^{2}$ M. Nowak, M. Smoleń-Wawrzusiszyn, Określanie intensyfikacji i innych cech kolorów w nazewnictwie handlowym, „Język Polski” 2003, z. 4-5, s. 267-272.

${ }^{3}$ K. Jurek, Znaczenie symboliczne i funkcje koloru w kulturze, „Kultura - Media - Teologia” 2011, nr 6, s. 68-80.

${ }^{4}$ A. Wierzbicka, Semantyka. Jednostki elementarne i uniwersalne, Lublin 2006, s. 353. 
Najwyraźniej różnice w zdolnościach widzenia można zobrazować, porównując widzenie ludzi i zwierząt. Różnimy się od siebie możliwościami rozróżniania samych barw, zakresem pola widzenia, wrażliwością na światło, wrażliwością na ruch i częstotliwość światła, głębią ostrości, ostrością wzroku. W niniejszej części uwagę skupię na samym postrzeganiu barwy.

Szczególnie ciekawe wydaje się porównanie postrzegania otaczającej rzeczywistości przez człowieka i zwierzęta. Porównajmy widzenie człowieka z innymi ssakami. Z biologicznego punktu widzenia zasadnicza różnica polega na tym, że pozostałe ssaki posiadają tylko dwa rodzaje czopków. Tego typu ograniczenia, wynikające $\mathrm{z}$ budowy receptorów, odbijają się bezpośrednio na zakresie odbieranych fal świetlnych, na przykład, wbrew obiegowej opinii, krowy i byki nie widzą czerwieni ${ }^{5}$, w związku z tym dosłowne rozumienie frazeologizmu Działać na kogoś jak czerwona plachta na byka nie ma potwierdzenia w świecie rzeczywistym. Inne zwierzęta, na przykład koty, widzą bardzo dobrze odcienie szarości, a ich wzrok w pełnym oświetleniu dziennym nie jest tak czuły, jak oko człowieka. Jego wzrok dostosowywał się przez tysiąclecia do specyficznego rodzaju aktywności tego zwierzęcia. Koty polują po zmroku i w ciemności, dlatego ich narządy wzroku są bardziej wyczulone na słabe natężenie światła, niestety kosztem ostrości widzenia. Jest to cena, jaką musiały ponieść za perfekcyjne przystosowanie się do działania w gorszych warunkach oświetleniowych ${ }^{6}$. Wśród ciemnego otoczenia trudniej rozróżnić odpowiednie kolory, dlatego znaczenia nabiera parametr ilości światła (jasność/ciemność). Dlatego kot bardzo dobrze widzi w zakresie kolorów achromatycznych. Potrafi rozróżnić więcej odcieni szarości niż człowiek, co prawdopodobnie pozwala mu lepiej łapać „,szare myszy”.

Porównajmy teraz krótko wzrok psa, który jest podobny do wzroku człowieka, lecz daltonisty. Psy należą do zwierząt dichromatycznych, czyli takich, które posiadają dwa rodzaje czopków. Pies nie odróżnia zakresu widma od czerwonego do zielonego, czyli generalnie psy mają świat pomalowany w dwóch kolorach - „na żółto i na niebiesko" plus odcienie szarości. $\mathrm{Z}$ tego powodu, na przykład, zielono-czerwona piłka o tym samym natężeniu i jasności obu barw będzie percepowana nie jako dwukolorowa, lecz mająca jeden szary odcień, czyli odbierana będzie przez receptory w formie jednego niepodzielnego wrażenia wizualnego.

Wśród innych zwierząt konie i kozy nie widzą błękitu, niebo jest dla nich szare, a owce nie widzą ani błękitu, ani czerwieni. Natomiast ssaki morskie posiadają tylko

${ }^{5}$ Do niedawna sądzono, że byki reagują agresywnie na czerwony kolor płachty toreadora, która zachęca je do ataku. Pogląd ten obaliły badania, które dowiodły, że byki nie widzą czerwieni, a w rzeczywistości rozjusza je ruch płachty.

${ }^{6}$ Koty posiadają na dnie oka specjalną błonę odbijającą światło, tzw. makatę. Makata odbija światło, kierując je z powrotem na siatkówkę, dzięki czemu zwiększa się stukrotnie wrażliwość na fale świetlne w porównaniu z człowiekiem. Nie bez znaczenia jest również możliwość większego poszerzenia się źrenic u kotów, co wpływa na wpadanie większej ilości światła do oka. 
jeden rodzaj czopków. Jest to tzw. widzenie monochromatyczne, czyli czarno-białe. Taki wzrok charakteryzuje m.in. delfiny czy lwy morskie, których wzrok nie odpowiada za widzenie kolorów, a jedynie odróżnianie kształtów.

Wg antropologów i kulturologów obecność u człowieka 3 receptorów kolorów miała swoje wymierne uzasadnienie, gdyż pozwalała odnajdywać w otaczającym bujnym środowisku roślinnym odpowiednie pożywienie. Miała ułatwiać dostrzeżenie dojrzałych owoców wśród gałęzi drzew czy też jagód, ziół i grzybów ukrytych w leśnym runie. Powszechnie uważa się, że najbardziej oddziałuje na człowieka kolor czerwony. Mark Changizi, amerykański neurobiolog, twierdzi, że dokładne widzenie barwy czerwonej najprawdopodobniej związane jest u ludzi z umiejętnością określania emocji oraz stanu zdrowia swoich towarzyszy. Nasze oczy przystosowane są do widzenia krwi napływającej pod skórę pod wpływem różnych stanów emocjonalnych (zagrożenia, strachu, szału, zawstydzenia, podniecenia) ${ }^{7}$. Według autorów książki Psychofizjologia widzenia wpływ kolorów na człowieka to nie tylko zwykły odbiór bodźca, ale złożony akt psychiczny, obejmujący cały organizm i osobowość patrzącego ${ }^{8}$. A czerwień, jak dalej twierdzą autorzy, „powoduje wyraźny wzrost ciśnienia krwi, przyspieszenie oddechu i tętna oraz zwiększenie częstotliwości mrugania powiekami..."

Natomiast narząd wzroku zwierząt jest dostosowany do warunków, w jakich one bytują. Dlatego tylko umownie można używać pojęć lepszy/gorszy wzrok, gdyż każde zwierzę dysponuje takim wzrokiem, jaki jest mu potrzebny na danym etapie rozwoju. Podobna sytuacja występuje w językach naturalnych. Językoznawcy przyznają, że nie ma ani prymitywnych, ani zaawansowanych języków. Każdy język powstał, aby zaspokajać potrzeby komunikacyjne odpowiedniej społeczności. Zatem każda społeczność posługuje się takim językiem, jaki jest jej potrzebny na odpowiednim szczeblu rozwoju i wystarczającym do zapewnienia komunikacji pomiędzy jej członkami.

Jak bardzo różnimy się od zwierząt w kwestii percepcji rzeczywistości świadczy chociażby fakt, że człowiek, chcąc poczuć temperaturę dotyka lub zbliża swoje ciało do źródła ciepła czy zimna. Natomiast niektóre zwierzęta czynią to w nieco inny sposób. Z. Dylewski pisze, że „Kret „widzi dotyk na odległość”, tj. reaguje na fale ciśnieniowe powietrza. Po przebiegu fali kret wie czy ma do czynienia z pająkiem, dżdżownicą, wężem, zawałem ziemi czy innym kretem, „widzi” nawet truchcik myszy w odległości 10 metrów"10.

${ }^{7}$ Zob.: A. Kukwa, Dlaczego widzimy w kolorze?, http://odkrywcy.pl/kat,111396,title,Dlaczegowidzimy-w-kolorze,wid,14974852,wiadomosc.html (10.06.2016).

${ }^{8}$ A. Mączyńska-Frydryszek, M. Jaskólska-Klaus, T. Maruszewski, Psychofizjologia widzenia, Poznań 2001.

${ }^{9}$ A. Mączyńska-Frydryszek, M. Jaskólska-Klaus, T. Maruszewski, Psychofizjologia..., op. cit., s. 163.

${ }^{10}$ Z. Dylewski, Rzeczywistość (1)... czyli co wiemy o naszym otoczeniu, zob. http://dylewski.com. $\mathrm{pl} /$ menu-boczne/zycie_mozgu/oddzialywanie-na-innych/ (10.06.2016). 
Przyjrzyjmy się przez chwilę percepcji barw przez ptaki i niektóre owady. Wiele z nich widzi niewidoczne dla człowieka promieniowanie ultrafioletowe. Jest to „kolor”, do którego nie ma dostępu człowiek. Nawet nie domyślamy się, jakie to może być wrażenie wizualne, gdyż zakres tych fal leży poza zdolnościami naszego aparatu widzenia. Skąd u niektórych zwierząt umiejętność widzenia w ultrafiolecie? Otóż ptaki mają cztery rodzaje czopków. Czwarty czopek odpowiada właśnie za widzenie w tym zakresie. Pszczoły, bąki i niektóre inne owady posiadają trzy rodzaje czopków, ale ich spektrum obejmuje również ultrafiolet. W praktyce pozwala to na podwojenie dostępnej palety kolorów. Zatem kolor biały będzie dla tych zwierząt miał różne odcienie znacznie różniące się siebie. Widzenie w ultrafiolecie ma również swoje praktyczne odbicie i jest bezpośrednio związane z zalotami zwierząt. Niektóre ptaki mają piękne wzory na upierzeniu widziane tylko w ultrafiolecie. Oprócz tego, takie widzenie pozwala ptakom drapieżnym widzieć z lotu ptaka o wiele więcej w porównaniu z człowiekiem. Pomaga im to, na przykład, w poszukiwaniu pożywienia. Kał i mocz pozostawiany na ziemi przez gryzonie absorbuje ultrafiolet, dzięki czemu ptak widzi z góry dokładnie ścieżki, po których poruszają się gryzonie, na które poluje $\mathrm{e}^{11}$.

Natomiast część owadów ma zakres percepcji przesunięty w stronę podczerwieni. Taką zdolnością cieszą się pluskwy, wszy i komary (te ostatnie widzą różnicę już przy $0,05^{\circ} \mathrm{C}$ ! $)^{12}$. Wyjątkowe możliwości widzenia posiada australijski chrząszcz (Merimna atrata), który dzięki bardzo czułym receptorom w zakresie podczerwieni potrafi ,zobaczyć” pożar z wielu kilometrów ${ }^{13}$.

Z powyższego krótkiego przeglądu wynika, że możliwości percepcyjne ludzi i zwierząt są niejednakowe. Dlatego i człowiek, i zwierzęta nie mogą odbierać otaczającego nas świata w identyczny sposób, widzą go odmiennie, co wpływa niewątpliwie na ich funkcjonowanie w środowisku zarówno społecznym, jak i naturalnym.

\section{Kategoryzacja barw w umyśle człowieka}

Postrzeganie barw przez człowieka i zwierzęta jest uwarunkowane czysto biologicznie, czyli ma obiektywne podstawy. Natomiast jak twierdzi A. Wierzbicka, to co pojawia się w mózgu, nie musi wcale być odzwierciedlane w umyśle w ten sam sposób ${ }^{14}$. Przecież nasz język odbija to, co dzieje się w umyśle. Zatem kategoryzacja barw następuje w umyśle i jest uwarunkowana czynnikami zarówno kulturowymi, jak i geograficznymi. W zakresie kolorów możemy mówić o głów-

${ }^{11}$ E. Nieckuła, Świat wedtug zwierząt, zob.: www.wprost.pl (10.06.2016).

${ }^{12}$ Z. Dylewski, Rzeczywistość (1)..., op. cit.

${ }^{13}$ Chrząszcz merimna atrata należy do owadów pirofilnych, które zasiedlają zgliszcza. Zob. H. Schmitz, A. Schmitz, H. Bleckmann, A new type of infrared organ in the Australian "ire-beetle" Merimna atrata (Coleoptera: Buprestidae), Naturwissenschaften, 2000, 87(12), s. 542-545.

${ }^{14}$ A. Wierzbicka, Semantyka. Jednostki elementarne i uniwersalne, Lublin 2006, s. 329. 
nych kategoriach nazywanych podstawowymi nazwami barw, które stanowią punkt odniesienia dla pozostałych odcieni kolorów. Kategoria podstawowych nazw barw powstaje jako rezultat procesu kategoryzacji, a jak uważa M. A. Krongauz, kategoryzacja to proces odniesienia obiektów do odpowiednich klas ${ }^{15}$. Przykładem naturalnych kategorii jest, na przykład, KOLOR ze swoimi znaczeniami 'biały', 'żółty', 'zielony' itd., tworzącymi system bazowych określeń kolorystycznych.

Powstaje pytanie, czy ludzie żyjący w różnych kulturach nakładają na spektrum barwne również swój indywidualny filtr kulturowy? Jak wykazały badania przeprowadzone przez Edwarda Sapira i Benjamina Lee Whorfa, każdy język należy rozpatrywać w kręgu tej lub innej kultury ${ }^{16}$. Mimo iż percepcja kolorów jest uwarunkowana czysto biologicznie, to sam proces kategoryzacji może przebiegać w różny sposób i przybierać odmienny charakter w różnych kulturach.

Zgodnie z klasycznym modelem kategoryzacji, mającym swoje podstawy jeszcze w starożytnej Grecji (prace Arystotelesa), kategorie definiowane są przez zestaw cech o charakterze binarnym (posiada kategorię lub nie posiada kategorii). Na przykład, w języku polskim kategoria WIŚNIOWY zawiera cechę +CZERWONY i cechę +CIEMNY, a nie posiada, na przykład, cechy -ZIELONY. Natomiast w języku rosyjskim kategoria АМАРАНТОВЫЙ może być zdefiniowana za pomocą cechy + +КРАСНЫЙ і +ФИОЛЕТОВЫЙ ${ }^{17}$. W takim przypadku kategorie posiadają wyraźnie zarysowane granice i definiowane są za pomocą zbioru cech koniecznych i wystarczających. W odróżnieniu od klasycznego modelu prototypowy model kategoryzacji został opracowany stosunkowo niedawno, bo w latach 70. XX w. Za twórcę uważa się przede wszystkim amerykańską psycholog - Eleanor Rosch. Jej zdaniem, przynależność do kategorii nie jest ostra, a egzemplarze należące do niej nie są równorzędne, ponieważ niektóre z nich są bardziej centralne (prototypowe). Wynika z tego, że kategorie są stopniowalne, od najlepszego przykładu do najbardziej oddalonego (peryferyjnego). W obrębie badań nad barwami wyznacza się prototypy barw dla odpowiednich zakresów spektrum widzialnego. Georges Kleiber uważa, że kategoria - jako rezultat kategoryzacji - posiada wewnętrzną strukturę prototypo$\mathrm{wą}^{18}$. Zatem kategoryzacja barw opiera się na teorii prototypów. I. M. Koboziowa twierdzi, że prototyp to „typowy, wzorcowy przedstawiciel klasy, kategorii” ${ }^{19}$. Dlatego prototypem koloru czerwonego jest ogień czy też krew, zielonego - roślinność, a białego - śnieg. Wyraz trawiasty będzie mieścił się w centrum kategorii ZIELONY, gdyż wyraża najlepszy przykład cechy zielony. Inna sytuacja zachodzi w przy-

${ }^{15}$ М.А. Кронгауз, Семантика, Москва 2001, s. 98.

${ }^{16}$ Zob.: E. Sapir, Kultura, język, osobowość: wybrane eseje, Warszawa 1978; B. Lee Whorf, Język, myśl i rzeczywistość, Warszawa 2002.

${ }^{17}$ A. Narloch, Цветообозначения в русском и польском языках: структурно-семантический, терминологический и когнитивный аспекты, Poznań 2013, s. 192.

${ }^{18}$ G. Kleiber, Semantyka prototypu - kategorie i znaczenie leksykalne, Kraków 2003, s. 51.

${ }^{19}$ И.М. Кобозева, Лингвистическая семантика, Москва 2000, s. 160. 
padku nazwy oliwkowy, która mieści się na peryferiach kategorii ZIELONY, ponieważ jest „gorszym” przykładem omawianej kategorii ze względu na jej mniejszą wyrazistość percepcyjną, oddalenie od prototypu zieleni. Badania znaczeń niepodstawowych nazw barw ze swoim centrum i peryferiami prezentuje Inna Bjelajeva, wykorzystując zaproponowany przez Georga Lakoff'a model kategorii radialnej ${ }^{20}$.

Jak uważa Ryszard Tokarski, ,językowe rozumienie barw to postrzeganie barwy poprzez kulturowo akceptowane obiekty-wzorce"21. Te wzorce-prototypy związane są z uniwersalnymi elementami ludzkiego poznania, do których odnosi Wierzbicka takie pojęcia jak dzień, noc, słońce, ogień, roślinność, niebo i ziemię ${ }^{22}$. Mimo istnienia tych uniwersalnych odniesień zakorzenionych w codziennym doświadczeniu człowieka wiele języków wykazuje rozbieżności w widzeniu barw, wyborze poszczególnych punktów odniesienia, granic kategorii, czy też ich ogniskowości.

Znaczne różnice w konceptualizacji barw występują wśród przedstawicieli odmiennych i oddalonych od siebie kultur. Dotyczą one podstawowych nazw barw, tj. nazw spełniających wyznaczone kryteria lingwistyczne. Kryteria te opisali Brent Berlin i Paul Kay w swojej pracy Basic colour terms ${ }^{23}$. Do grona podstawowych (bazowych) określeń kolorystycznych możemy zaliczyć wyrazy synchronicznie niemotywowane, monoleksemiczne, o szerokim zakresie łączliwości, semantycznie niepodporządkowane innej nazwie barwy. Grupa podstawowych nazw barw stanowi trzon utrwalonych jednostek językowych wyrazistych psychologicznie, które są łatwo identyfikowane $\mathrm{z}$ odpowiednimi klasami obiektów rzeczywistości pozajęzykowej, będących ich prototypowymi wzorcami. Podstawowe nazwy barw zalicza się do słownictwa podstawowego w odróżnieniu od nazw pochodnych, których zakres użycia jest węższy lub ograniczony do odpowiedniej klasy denotatów.

Kolor jako taki może być również podciągnięty pod zupełnie inne kategorie. Rosch badająca język plemienia Dani (Nowa Gwinea) podaje, że język ten posiada tylko dwie podstawowe nazwy kolorów mili i mola ${ }^{24}$. Najlepsze przykłady mili obejmują swoim zakresem kolory ciemne i ,zimne”, a najlepszymi przykładami są najciemniejsze zielenie i odcienie niebieskiego. Natomiast nazwa mola wiąże się z barwami jasnymi i „ciepłymi”, a najlepszym przykładem jest ciemna czerwień i rzadziej blady kolor różowy ${ }^{25}$. John Taylor pisze, że w języku tonga (jeden z języków bantu grupy nigerokongijskiej) jest siedem podstawowych nazw barw. Nazwą ribungu określane są takie barwy jak żółta, pomarańczowa i brązowa charakteryzu-

${ }^{20}$ I. Bjelajeva, Niepodstawowe nazwy barw $w$ języku polskim, czeskim, rosyjskim $i$ ukraińskim, Warszawa 2005, s. 32-33.

${ }^{21}$ R. Tokarski, Semantyka barw we współczesnej polszczyźnie, Lublin 1995, s. 168.

${ }^{22}$ А. Вежбицкая, Язык. Культура. Познание, Москва 1996.

${ }^{23}$ B. Berlin, P. Kay, Basic Color Terms. Their Universality and Evolution, Berkeley 1969, s. 5-7.

${ }^{24}$ Heider, Eleanor Rosch, Probabilities, sampling and the ethnographic method: The case of Dani colour names. Man 7, 1972, s. 451.

${ }^{25}$ Heider, Eleanor Rosch, Probabilities..., op. cit. 
jące się małym stopniem czystości. Natomiast nazwa tshwuka obejmuje swoim zakresem czerwony, różowy i fioletowy ${ }^{26}$.

Harold Conklin podaje przykład języka hanunoo, który posiada cztery podstawowe nazwy barw, które można określić jako: 'ciemny/czarny', 'jasny/biały', 'czerwony' i 'zielony/jasnozielony'. Dwie ostatnie kategorie 'czerwony' i 'zielony/jasnozielony’ stoją w opozycji do siebie względem kategorii wilgotności/suchości i .

W wielu językach świata istnieje jedna nazwa dla koloru niebieskiego i zielonego. Paul Kay i Chad K. McDaniel nazywają tę kategorię grue ${ }^{28}$ (kontaminacja wyrazów green i blue). Kategorię tę można odnotować w języku Indian Nawaho, języku jakuckim (küöh), japońskim (aoi). Nierozerwalność niebieskiego i zielonego zauważamy również w języku czeczeńskim - сийнa, czy kazachskim - көк. Tadżyckie kabud oznacza niebieski, jak i w niektórych przypadkach także zielony ${ }^{29}$. W językach zulu również nie ma odrębnych określeń dla barw niebieskiej i zielonej ${ }^{30}$. Istnieją jednak społeczności, w których kategoria barwy nie odgrywa tak istotnej roli w codziennym życiu. Na przykład w języku Indian Piraha, zamieszkujących Amazonię w Ameryce Południowej, nie ma oddzielnych nazw barw ${ }^{31}$. Natomiast sam kolor może być wyrażony konstrukcją porównawczą typu: ,jak ogień”, ,jak krew”, ,jak niebo".

Różnice w kategoryzacji na poziomie nazw podstawowych są mniej zauważalne wśród języków europejskich, które oscylują wokół jednego wspólnego kręgu kulturowego. Jednakże występują również i tu. Na przykład niektórzy badacze (Berlin i Kay, Forbes, Frumkina) podają, że w języku węgierskim występują dwie nazwy, piros i voros, dla angielskiego odpowiednika red. Louis Hjelmslev, porównując strukturę kategorialną kolorów w języku walijskim i angielskim, wykazuje, że walijskiemu określeniu glas odpowiadają w języku angielskim aż trzy określenia barwy green, blue lub grey ${ }^{32}$.

Porównując granice barw w językach słowiańskich zauważymy, że w języku rosyjskim polskiemu określeniu niebieski odpowiadają dwie nazwy синий і голубой. Taka sytuacja wynika zapewne z tego, że jeszcze w literaturze okresu XI w. w wielu przypadkach синий przekazuje znaczenie ciemnego koloru i ma wąską łączliwość (zbiorniki wodne i niektóre zjawiska przyrodnicze) ${ }^{33}$. Ścisłe związki синий z wodą nie mogły nie odbić piętna na postrzeganiu tej barwy. W mitologii i wierzeniach słowiań-

${ }^{26}$ J. Taylor, Kategoryzacja w języku: prototypy w teorii językoznawczej, Kraków 2001, s. 23.

${ }^{27}$ H. Conklin, Hanunóo Color Categories, "Southwestern Journal of Anthropology", Vol. 11, No. 4. pg. 339-344.

${ }^{28}$ Cyt. za A. Wierzbicka, Semantyka..., op. cit., s. 360.

${ }^{29}$ М.М. Атоева, Лексика, обозначающая ивет в таджикском и русском языках, Автореферат дисс. на соис. уч. ст. кан. фил. наук, Душанбе 1988.

${ }^{30}$ J. Taylor, Kategoryzacja..., op. cit., s. 35.

${ }^{31}$ D. Everett, Cultural Constraints on Grammar and Cognition in Piraha: Another Look at the Design Features of Human Language, "Current Anthropology”, Vol. 46, Nr 4, 2005, s. 55.

${ }^{32}$ Cyt. za: M. Taverniers, Hjelmslev's semiotic model of language: An exegesis, http://users.ugent. be/ mtaverni/publications.html (10.06.2016)

${ }_{33}$ А.П. Василевич, С.С. Мищенко, Синий, синий, голубой, [w:] А.П. Василевич, С.Н. Кузнецова, С.С. Мищенко, Цвет и названия ивета в русском языке, Москва 2008, s. 43. 
skich woda uważana była jako miejsce, gdzie żyją złe, wrogie człowiekowi siły. Od zamierzchłych czasów woda uważana była za żywioł, związany ze śmiercią i światem pozagrobowym ${ }^{34}$. Z kolorem синий związane są liczne obrzędy i zabobony ludowe. Osoby z oczami takiej barwy wzbudzały strach. Sądzono, że obdarzone były siłami magicznymi. Według podań Iwan Groźny panicznie bał się ludzi z takimi właśnie oczami. Obciążenia kulturowe odbiły się na negatywnych konotacjach tego słowa.

Natomiast nazwa голубой - przeciwne, obrosła w pozytywne skojarzenia, gdyż wiązała się z kolorem nieba, czyli jasnym odcieniem niebieskiego. Etymologicznie słowo odnosi się do gołębia i koloru piór. Dlatego początkowo słowo голубой wyrażało kolor szary, niebiesko-szary, charakteryzując maści zwierząt. Jak podaje Roza W. Alimpijewa, od XVII w. голубой uzyskuje znaczenie 'jasnoniebieski'35. Co spowodowało te zmiany? Zdaniem Alimpijewy należy najpierw odrzucić wyjaśnienie faktu poprzez ewolucje wzorca kolorystycznego (upierzenia gołębia). Pozostają pewne asocjacje, lecz nie kolorystyczne, a bardziej skomplikowane - kulturologiczne, uwarunkowane duchowymi, chrześcijańskimi wartościami narodu rosyjskiego ${ }^{36}$. Niewykluczone, że silne pozytywne i negatywne konotacje tych dwóch nazw w pewnym stopniu stały się jednym z czynników kształtowania się dwóch zakresów kolorystycznych jako odrębnych kategorii.

Przy porównaniu rosyjskich nazw синий і голубой z ukraińskimi odpowiednikami niektórzy badanie zauważają pewne różnice. Galina Javorska wydziela w języku ukraińskim trzy podstawowe nazwy barw dla spektrum pola niebieski. Są to nazwy: блакитний, голубий, синій ${ }^{37}$. Autorka uzasadnia dodanie przymiotnika блакитний do zestawu nazw bazowych istotną rolą, jaką pełni on w systemie nazewniczym współczesnych ukraińskich nazw barw. Oprócz tego, jak stwierdza Javorska, „Wyraz ten odpowiada wszystkim niezbędnym kryteriom wydzielenia podstawowych nazw barw: jest niepochodny, ma szeroki zakres łączliwości, jest stylistycznie neutralny, cechuje go wyrazistość psychologiczna, jego prototyp niebo w jasny, słoneczny dzień - nie budzi wątpliwości”38. A zatem, jak wynika z powyższego, każdy język może dzielić spektrum barwne indywidualnie i niezależnie od innych języków.

${ }^{34}$ А.П. Василевич, С.С. Мищенко, Синий..., ор. cit.

${ }^{35}$ Р.В. Алимпиева, Этнокультурный компонент текста как средство выражения русского национального самосознания, [w:] Семантические единицы русского языка в диахронии и синхронии: сборник научныхх трудов, red. С.С. Ваулина, Калининград 2002, s. 8-9.

${ }^{36}$ Jak podaje R.W. Alimpijewa, właśnie w formie gołębia zszedł Duch Święty na Chrystusa w czasie chrztu w rzece Jordan. Zatem w chrześcijańskim postrzeganiu gołąb jest czymś pomiędzy człowiekiem a Bogiem, elementem łączącym. Symbolika ta mogła odbić się na semantyce leksemu голубой, aktywizując znaczenie odcienia jasnoniebieskiego i przyciąganie do strefy „nieba”, zob.: Р.В. Алимпиева, Этнокультурный..., ор. cit., s. 10-12.

${ }^{37}$ G. Javorska, O podstawowych nazwach barw w języku ukraińskim (materiały do badań porównawczych), [w:] Studia z semantyki porównawczej, nazwy barw, nazwy wymiarów, predykaty mentalne, cz. 1, red. R. Grzegorczykowa, K. Waszakowa, Warszawa 2000, s. 30-31.

${ }^{38}$ G. Javorska, O podstawowych..., op. cit., s. 30. 


\section{Konceptualizacja niepodstawowych nazw barw w języku polskim i rosyjskim}

Zgodnie z zasadą relatywizmu językowego, języki dysponują własną siatką podziału i systematyzacji świata. Zaprezentowane przykłady potwierdzają również różną konceptualizację w obrębie podstawowych nazw barw. Powstaje pytanie, czy w grupie niepodstawowych nazw (wtórnych, motywowanych), które są hiponimami w stosunku do podstawowych nazw barw, również występują różnice znaczeniowe pomiędzy nazwami barw w języku polskim i rosyjskim? Zakładam, że w językach blisko spokrewnionych różnice w semantyce nazw barw nie będą wykazywać znaczących różnic na poziomie jednostek mających wspólny wzorzec motywujący. W tym przypadku za najbardziej wiarygodne źródła opisu znaczenia jednostek kolorystycznych uznaję słowniki języka rosyjskiego i polskiego. W nielicznych przykładach, na skutek braku eksplikacji znaczenia barwy przez źródła leksyko-graficzne, odwołuję się do danych zaczerpniętych od respondentów.

Niepodstawowe nazwy barw tworzone są na bazie nazw przedmiotów, charakteryzujących się pewną stałością barwy. Stereotypowość kolorystyczna obiektu wpływa na stabilizację w świadomości ludzkiej niezmiennego obrazu wizualnego, w tym jakości kolorystycznej. Większość tych obiektów wspólna jest dla różnych kultur i reprezentowana przez takie pojęcia jak roślinność, niebo, ziemia, krew, śnieg itd. Również wiele innych, mniej charakterystycznych, obiektów staje się wzorcami barw. Możemy do nich zaliczyć powszechnie występujące i szeroko znane obiekty takie, jak: owoce, warzywa, napoje, potrawy, obiekty przyrody nieożywionej. W języku polskim i rosyjskim wiele nazw posiada wspólny wzorzec motywujący. Na przykład, w obu językach mamy nazwę barwy, której wzorcem motywującym stał się metal - platyna. Stownik wspótczesnego języka polskiego pod redakcją Bogusława Dunaja w znaczeniu koloru podaje następującą definicję platynowy: „zwykle o włosach, ich kolorze: taki jak platyna, koloru platyny, srebrzystobiały; mający taki odcień włosów" (SWJP, 755). W podobny sposób notuje słowo rosyjski Словарь ивета, por.: платиновый 'о почти белом цвете волос, бороды, 39 . $\mathrm{W}$ obu przypadkach dominantą kolorystyczną stał się biaty. Brak dywergencji semantycznych można odnotować w parze малахитовый i malachitowy. Dane leksykograficzne podają zbliżone definicje semantyczne, dlatego można uznać ich znaczenia za tożsame, por. малахитовый 'ярко-зелёный' (СРЯ, II: 218), (НСРЯ, I: 822), malachitowy jako ‘szmaragdowozielony' (SJPD, IV: 398), (PSWP, XX: 159), (SJPSz, II: 95). W obu przymiotnikach dominantą kolorystyczną staje się zielony.

Jednakże niektóre jednostki, mimo że zawierają ten sam etymon, należą do różnych ognisk kolorystycznych w obu językach. Przykładem takich różnic mogą być leksemy гранатовый i granatowy. Polski koloratyw zaliczany jest do dominanty

${ }^{39}$ В.К. Харченко, Словарь ивета: реальное, потенциальное, авторское: свыше 4000 слов в 8000 контекстах, Москва 2009, s. 318. 
niebieskiego (PSWP, XIII: 48), (SJPSz, I: 693), natomiast rosyjski odpowiednik гранатовый do dominanty czerwonego i wyraża znaczenie 'ciemnoczerwony', por.: „темно-красный, цвета граната” (ТСРЯ, 143). Obie nazwy mają wspólny wzorzec kolorystyczny - owoc granatu. Tokarski uzasadnił znaczenie polskiego leksemu jego transformacją semantyczną od koloru granatu (czerwony) do ciemnoniebieskiego ${ }^{40}$. Jeden $\mathrm{z}$ polskich słowników uzasadnia zmianę pierwotnego znaczenia w następujący sposób: ,początkowo granatem nazywano kolor ciemnoczerwony, przypominający kolor owocu granatowca, sok z granatu plami tkaniny na kolor ciemnoniebieski, czyli na granat" (PSWP, XIII: 47).

Leksyka kolorystyczna wykazuje ponadto pewne nieznaczne odchylenia semantyczne w poszczególnych parach wyrazów. Wynikają one z różnej konceptualizacji tych jednostek, a uwarunkowane mogą być zarówno czynnikami geograficznymi, jak i kulturowymi. Nieznaczne różnice semantyczne ujawniają się na poziomie nazw pomidorowy і томатный. Praktyczny słownik współczesnej polszczyzny podaje, że jest to ,kolor owoców pomidora - czerwony z odcieniem pomarańczowym”(PSWP, XXX: 286). Natomiast rosyjskie помидоровый posiada znaczenie: 'Имеющий ц̧вет помидора, ярко-красный (обычно о щеках, румянце и т.n.)' (БТСРЯ, 915). Brak paraleli pomiędzy tymi jednostkami przejawia się w występowaniu w języku polskim dodatkowego komponentu semantycznego - semu 'pomarańczowy', którego brak w języku rosyjskim. Czyżby kolor pomidorów różnił się nieznacznie w obu kręgach kulturowych? Niewykluczone, że wzorcem stał się różny stopień dojrzałości tych warzyw, czy też rozpowszechnienie konkretnych gatunków, których płody przybierają różne odcienie ${ }^{41}$. Weźmy inną parę przymiotników - маффранный i szafranowy. Za wzór barwy posłużył szafran (ros. шафран) 'rodzaj roślin z rodziny kosaćcowatych'. Wysuszone części kwiatów tej rośliny wykorzystuje się jako przyprawę, mającą pomarańczowo-żółty kolor. Czterotomowy Словарь русского языка określa kolor шафранный jako 'оранжево-жёлтый, как будто выкрашенный шафраном' (CPЯ, IV: 704), czyli 'pomarańczowożółty’. Z kolei inne źródło wzbogaca ten odcień o dodatkowy komponent semu „коричневатый” (pol. „,brązowawy”) (БТСРЯ: 1492) ${ }^{42}$. Tymczasem słowniki języka polskiego podkreślają

${ }^{40}$ Inni polscy badacze S. Skwarczyńska i A. Zaręba również wskazują na związek przymiotnika granatowy z owocem granatu. Zdaniem S. Skwarczyńskiej, pierwotnie przymiotnik oznaczał nasycony kolor czerwony (lub purpurowy). Następnie ciemnoniebieski odcień owocu zaczął dominować nad bazowym czerwonym. Przymiotnik granatowy oznaczał odcień koloru ciemnoczerwonego jeszcze u A. Mickiewicza. Inne uzasadnienie podaje A. Zaręba, wiążąc powstanie koloru od nazwy tkaniny granat. Zob.: A. Zaręba, Nazwy barw w dialektach i historii języka polskiego, Wrocław 1954, s. 53-54; S. Skwarczyńska, Wartość treściowa kolorów w romantyzmie a dzisiaj, „Pamiętnik Literacki”, nr XXIX, z. III-IV, Lwów 1932.

${ }^{41} \mathrm{Na}$ rynku handlowym występują różne odmiany pomidorów, które mogą być czerwone, żółte, pomarańczowe, malinowe, zielone, a nawet „czarne”.

${ }^{42}$ Warto odnotować, że słownik D.N. Uszakowa wprowadza jeszcze odcień czerwieni dla koloru шафранныци, por. 'цвета шафрана, красновато-жёлтый', zob. (ТСРЯУ, IV: 1324). 
intensywność koloru żółtego, bez wskazywania na obecność odcienia pomarańczowego, por. 'intensywnie żółty' (SWJP, II: 1083), (SJPD, VIII: 1002), (SJPSz, III: 390).

Różnice w konceptualizacji nazw barw mogą dotyczyć nie tylko różnic $\mathrm{w}$ odcieniu par wyrazów w poszczególnych językach. Niekiedy obserwujemy brak odpowiedniości semantycznej między nazwami, mającymi ten sam wzorzec motywujący, a przejawiający się na poziomie odniesienia nazwy do odpowiedniej dominanty kolorystycznej. Leksem земляничный rejestruje ТСРЯ w znaczeniu 'розовато-красный, ивета земляники' (ТСРЯ: 229), czyli należy on do dominanty czerwonego. Jednakże część słowników języka polskiego zalicza barwę poziomki do dominanty koloru różowego, o czym zaświadczają definicje leksemu: 'o kolorze: taki jak poziomka, różowawy' (SWJP, II: 836), 'mający barwę poziomki, różowy rozbielony' (SJPSz, II: 888).

Różna konceptualizacja barwy w języku polskim i rosyjskim może zachodzić w przypadku, kiedy obiekt, będący wzorcem kolorystycznym, nie wykazuje jednoznacznej przynależności do jednej z podstawowych nazw barw, a zajmuje pozycję pośrednią, leżącą na skali pomiędzy dwoma barwami. W takim przypadku trudno znaczenie wyrazu jednoznacznie zaliczyć do jednej z dominant. Efektem takiego zróżnicowanego postrzegania są leksemу цикламеновый i cyklamenowy. Rosyjskie иикламеновый zgodnie $\mathrm{z}$ definicją słownikową oznacza: 'ивета иикламена; розово-фиолетовый' (БТСРЯ, 1463). Zatem bazę kolorystyczną tworzy kolor fioletowy. Opierając się na danych z polskich słowników, powinniśmy odnieść przymiotnik cyklamenowy do dominanty koloru różowego, por. ' $\mathrm{w}$ kolorze cyklamenów, czyli różowy z odcieniem fioletowym' (PSWP, VII: 331). Mały słownik języka polskiego nie wyklucza również dominanty czerwonego, por.: 'kolor czerwony lub różowy o odcieniu fioletowym' (MSJP, 103).

Pewne trudności powstają przy zakwalifikowaniu do odpowiedniej dominanty przymiotników mиsztardowy і горчичный. Oba leksemy posiadają wspólny wzorzec - musztardę. $\mathrm{Z}$ reguły musztarda posiada różny kolor i waha się w przedziale żółto-brązowych odcieni. Słowniki języka polskiego odnotowują następujące znaczenia przymiotnika: 'taki, którego składnikiem jest musztarda lub który ma smak, kolor musztardy' (SWJP, 545), 'taki, który ma związek z musztardą; taki, który zawiera musztardę: kolor musztardowy' (PSWP, 22: 140), 'przym. od musztarda: Sos musztardowy. Kolor musztardowy' (SJPSz, 2: 231). Jak widać, słowniki nie eksplikują konkretnej dominanty. Dlatego konieczne stało się odwołanie do respondentów, z których dwie trzecie określiło barwę musztardy jako żółtą. Trudności w eksplikacji znaczenia pojawiają się w nazwie горчичный. Na przykład W.K. Charczenko i I. Bjelajeva odnoszą znaczenie przymiotnika do dominanty żółtego. Revekka M. Frumkina na podstawie badań psycholingwistycznych zaliczyła jednostkę do odcieni koloru zielonego. Natomiast źródła leksykograficzne umieszczają znaczenie wyrazu w spektrum koloru brązowego jako 'żółtawobrązowy', por.: 'Имеющий ивет горчицы; желтовато-коричневый' (БТСРЯ, 221). Nosiciele języka rosyjskiego również niejednoznacznie wypowiadali się na temat przewagi jednej z dominant, 
podzieliwszy swoje opinie. W planie semantycznym przymiotnik ten odnosi się do jednego z najtrudniej definiowalnych określeń kolorystycznych.

Asymetria znaczeń w nazewnictwie kolorystycznym przejawia się pomiędzy rosyjskim стальной i polskim stalowy. Znaczenie rosyjskiego przymiotnika cmaльной skupia się wokół dominanty szarego koloru. Słowniki rejestrują leksem w następujący sposób: 'Блещущиий серый, холодным блеском похожий на сталь. Цвет воды в пасмурный день' (СЦ, 439). Autor wzbogaca znaczenie о komponent 'zimny'. Obecność w semantyce koloru znaczenia temperaturowego niewątpliwie uwarunkowana jest tym, że metal kojarzy się z czymś chłodnym, zimnym. Dlatego tak często wykorzystywany jest do opisu obiektów wodnych. Natomiast określenie znaczenia polskiego przymiotnika stalowy bynajmniej nie jest takie proste. Opierając się na się polskich źródłach leksykograficznych, leksem stalowy należy zaliczyć nie do szarych odcieni, lecz niebieskich! Por. definicje słownikowe: 'mający kolor stali; szaroniebieski, niekiedy z metalowym połyskiem' (PSWP, 40: 163), 'mający kolor stali; szaroniebieski' (SWJP, 2: 1055). Takie rozumienie nie idzie w parze $\mathrm{z}$ danymi dostarczonymi przez respondentów. Uznali oni bowiem, że stalowy to odcień koloru szarego. Tylko nieznaczna ilość wskazywała na dominantę niebieskiego. Wydaje się jednak, że powinniśmy przymiotnik stalowy określać raczej jako 'szary z niebieskawym odcieniem', czyli zaliczyć go do dominanty koloru szarego, a nie niebieskiego. Różnic w kategoryzacji barw w obu językach jest znacznie więcej, jednakże w niniejszym opracowaniu chciałem tylko poruszyć tę problematykę, która wymaga jeszcze dalszych szczegółowych badań.

\section{Podsumowanie}

Porównanie zdolności percepcyjnych człowieka i zwierząt pozwoliło na stwierdzenie, że istotną rolę w samym postrzeganiu barw odgrywa fizjologia, ponieważ biologiczna budowa receptorów wzrokowych determinuje zdolność wykrywania odpowiedniego zakresu promieniowania elektromagnetycznego, a tym samym widzenia tej czy innej barwy. Fizjologia wpływa na postrzeganie barw, ponieważ jest uwarunkowana czysto biologicznie. Jak dowodzą badania, percepcja kolorów ma charakter dość uniwersalny. Ludzie w ten sam sposób postrzegają barwy. Jednakże kolejnym ważnym elementem, który należy wziąć pod uwagę, jest kategoryzacja dokonująca się w umyśle człowieka, która z kolei odbija się w języku w postaci funkcjonowania systemu nazewnictwa barw. Kategoryzacja barw uwarunkowana jest czynnikami przyrodniczo-geograficznymi, jak i kulturowo-społecznymi.

Z czynnikami geograficznymi związana jest niestabilność kolorystyczna wzorca, jego zmienność. Czynniki geograficzne determinują funkcjonowanie obiektów i ich związków z wzorcami ze względu na specyfikę i warunki samego otoczenia, klimatu, temperatury, występowania odpowiednich modeli kolorystycznych. 
Z czynnikami kulturowymi związane jest obieranie tego lub innego fragmentu otaczającej rzeczywistości jako elementu wyeksponowanego kulturowo. Wszystko to dowodzi, że granice między nazwami barw są dość płynne, zmienne i nietrwałe, a z biegiem czasu semantyka niektórych nazw może ulec transformacjom. Porównując dwa języki - polski i rosyjski - można stwierdzić, że w grupie niepodstawowych nazw barw konceptualizacja danej kategorii również nierzadko przebiega w odmienny sposób. Mamy tu do czynienia, z jednej strony, z tożsamością znaczeń odpowiednich par przymiotników, $\mathrm{z}$ drugiej $-\mathrm{z}$ zawężeniem lub poszerzeniem znaczenia w jednym z nich, czy też - pełnym brakiem ekwiwalencji.

\section{Wykaz skrótów:}

MSJP - Mały słownik języka polskiego, red. E. Sobol, Warszawa 1999.

PSWP - Praktyczny słownik współczesnej polszczyzny, red. H. Zgółkowa, t. 1-50, Poznań 1994-2005.

SJPD - Stownik języka polskiego, red. W. Doroszewski, t. I-XI, Warszawa 1969-1978.

SJPSz - Stownik języka polskiego, red. M. Szymczak, t. 1-3, Warszawa 1978-81.

SWJP - Słownik współczesnego języka polskiego, red. B. Dunaj, Warszawa 1999.

БТСРЯ - Большой толковый словарь русского языка, под ред. С.А. Кузнецова, Санкт-Петербург 1998.

НСРЯ - Т.Ф. Ефремова, Новый словарь русского языка, Толково-словообразовательный, т. 1-2, Москва 2000.

СРЯ - Словарь русского языка: в 4 томах, под ред. А.П. Евгеньевой, Москва 1981-1984.

СЦ - В.К. Харченко, Словарь ивета, Москва 2009.

ТСРЯ - С.И. Ожегов, Н.Ю. Шведова, Толковый словарь русского языка, Москва 1999.

ТСРЯУ-Толковый словарь русского языка: В 4 т., под ред. Д.Н. Ушакова, Москва 1935-1940.

\section{Bibliografia}

Berlin, B. i P. Kay. 1969. Basic color terms. Their universality and evolution. Berkeley: University of California Press.

Bjelajeva, I. 2005. Niepodstawowe nazwy barw w języku polskim, czeskim, rosyjskim i ukraińskim. Warszawa: Wydział Polonistyki Uniwersytetu Warszawskiego.

Conklin, H. 1955. "Hanunóo color categories". Southwestern Journal of Anthropology 11. 4. 339-344.

Dylewski, Z. „Rzeczywistość (1)... czyli co wiemy o naszym otoczeniu”. http://dylewski.com. pl/menu-boczne/zycie_mozgu/oddzialywanie-na-innych/ (10.06.2016).

Everett, D. 2005. "Cultural constraints on grammar and cognition in Piraha: another look at the design features of human language". Current Anthropology 46.4. 621-646.

Heider Rosch, E. 1972. "Probabilities, sampling and the ethnographic method: The case of Dani colour names". Man 7.3. 448-466.

Javorska, G. 2000. „O podstawowych nazwach barw w języku ukraińskim (materiały do badań porównawczych)". W zbiorze: Grzegorczykowa, R. i K. Waszakowa (red.). Studia z seman- 
tyki porównawczej, nazwy barw, nazwy wymiarów, predykaty mentalne. Cz. 1. Warszawa: Wydawnictwa Uniwersytetu Warszawskiego.

Jurek, K. 2011. „Znaczenie symboliczne i funkcje koloru w kulturze”. Kultura-Media-Teologia 6. $68-80$.

Kleiber, G. 2003. Semantyka prototypu - kategorie i znaczenie leksykalne. Kraków: Universitas.

Kukwa, A. „Dlaczego widzimy w kolorze?”. http://odkrywcy.pl/kat,111396,title,Dlaczego-widzi my-w-kolorze, wid,14974852, wiadomosc.html (10.06.2016).

Mączyńska-Frydryszek, A., Jaskólska-Klaus M. i T. Maruszewski. 2001. Psychofizjologia widzenia. Poznań: Akademia Sztuk Pięknych w Poznaniu.

Narloch, А. 2013. Цветообозначения в русском и польском языках: структурно-семантический, терминологический и когнитивный аспекты. Poznań: Wydawnictwo Naukowe UAM.

Nieckuła, E. „Świat według zwierząt”. www.wprost.pl (10.06.2016).

Nowak, M. i M. Smoleń-Wawrzusiszyn. 2003. „Określanie intensyfikacji i innych cech kolorów w nazewnictwie handlowym". Język Polski 4-5. 267-272.

Sapir, E. 1978/2002. Kultura, język, osobowość: wybrane eseje. Warszawa: Państwowy Instytut Wydawniczy.

Schmitz, H., Schmitz, A. i H. Bleckmann. 2000. "A new type of infrared organ in the Australian "fire-beetle" Merimna atrata (Coleoptera: Buprestidae)". Naturwissenschaften 87.12. 542-545.

Skwarczyńska, S. 1932. „Wartość treściowa kolorów w romantyzmie a dzisiaj”, Pamiętnik Literacki XXIX. III-IV. 273-301.

Taylor, J.R. 2001. Kategoryzacja $w$ języku: prototypy $w$ teorii językoznawczej. Kraków: Universitas.

Tokarski, R. 1995. Semantyka barw we współczesnej polszczyźnie. Lublin: Wydawnictwo UMCS.

Taverniers, M. "Hjelmslev's semiotic model of language: an exegesis". http://users.ugent.be/ mtaverni/pdfs/Taverniers_2007_Hjelmslev-PP.pdf (10.06.2016)

Whorf, B. L. 2002. Język, myśl i rzeczywistość. Warszawa: Wydawnictwo KR.

Wierzbicka, A. 2006. Semantyka. Jednostki elementarne $i$ uniwersalne. Lublin: Wydawnictwo UMCS.

Zaręba, A. 1954. Nazwy barw w dialektach $i$ historii języka polskiego. Wrocław: Zakład im. Ossolińskich.

Алимпиева, Р.В. 2002. „Этнокультурный компонент текста как средство выражения русского национального самосознания”. [в:] Семантические единицы русского языка в диахронии и синхронии: сборник научных трудов, red. С.С. Ваулина, Калининград.

Атоева, М.М. 1988. Лексика, обозначающая цвет в таджикском и русском языках. Автореферат дисс. на соис. уч. ст. кан. фил. наук. Душанбе.

Василевич, А.П. и С.С Мищенко. 2008. „Синий, синий, голубой”. [в:] А.П. Василевич, С.Н. Кузнецова, С.С. Мищенко. Цвет и названия ивета в русском языке. Москва.

Вежбицкая, А. 1996. Язык. Культура. Познание. Москва.

Кобозева, И.М. 2000. Лингвистическая семантика. Москва.

Кронгауз, М.А. 2001. Семантика. Москва. 
